\title{
Chlamydia spp. in free-living domestic pigeons
}

\section{Chlamydia spp. em pombos de vida livire}

\section{Chlamydia spp. en palomas de vida libre}

Kelly Cristiny Gomes da Paixão Albuquerque ORCID: https://orcid.org/0000-0001-7633-7644 Federal University of Pará, Brazil

E-mail: kellycpaixao@yahoo.com.br

Bruna Alves Ramos

ORCID: https://orcid.org/0000-0003-4803-7825 Evandro Chagas Institute, Brazil E-mail:minohrah@gmail.com Andrea Viana da Cruz ORCID: https://orcid.org/0000-0002-6532-8424 Federal University of Pará, Brazil

E-mail: andrea.vianacruz@gmail.com

Sandro Patroca da Silva ORCID: https://orcid.org/0000-0001-7185-4538 Evandro Chagas Institute, Brazil E-mail: spatroca@gmail.com

Lívia Medeiros Neves Casseb ORCID: https://orcid.org/0000-0001-8578-9984 Evandro Chagas Institute, Brazil

E-mail: liviacasseb@iec.pa.gov.br

Jannifer Oliveira Chiang

ORCID: https://orcid.org/0000-0002-6667-2796

Evandro Chagas Institute, Brazil

E-mail: janniferchiang@iec.gov.br

Thamillys Rayssa Marques Monteiro

ORCID: https://orcid.org/0000-0002-4763-5316

Federal Rural University of the Amazon, Brazil E-mail: thamillysmonteiro@gmail.com

Barbara Wilka Leal Silva

ORCID: https://orcid.org/0000-0002-4055-4302 Federal Rural University of the Amazon, Brazil E-mail: leal.barbara193@gmail.com

Camila de Cássia dos Santos

ORCID: https://orcid.org/0000-0002-7860-1565 Federal Rural University of the Amazon, Brazil camilamedvs@gmail.com

Keila Feitosa Valente

ORCID: https://orcid.org/0000-0001-8965-5123 Federal Rural University of the Amazon, Brazil E-mail: keilavalente.vet@gmail.com

Pedro Henrique Marques Barrozo ORCID: https://orcid.org/0000-0002-0594-3150 Federal Rural University of the Amazon, Brazil E-mail: pedro2011ph@ hotmail.com

Caroliny do Socorro Brito Santos ORCID: https://orcid.org/0000-0002-7360-0563 Federal Rural University of the Amazon, Brazil E-mail: caroliny.bsantos@gmail.com

Pâmela Talita de Aguiar e Silva ORCID: https://orcid.org/0000-0001-5711-4680 Federal Rural University of the Amazon, Brazil

E-mail: silvapamelatalita@gmail.com

Elem Cristina Macedo Barra ORCID: https://orcid.org/0000-0002-5799-8954 Federal Rural University of the Amazon, Brazil E-mail: elem.c.m.b@gmail.com

Fernanda Monik Silva Martins ORCID: https://orcid.org/0000-0003-4161-0027 Federal Rural University of the Amazon, Brazil

E-mail: fernanda.martins.ufra@gmail.com 


\author{
Andréa Maria Góes Negrão \\ ORCID: https://orcid.org/0000-0002-2064-0772 \\ Federal Rural University of the Amazon, Brazil \\ E-mail: andreamariagn@gmail.com \\ Alexandre do Rosário Casseb \\ ORCID: https://orcid.org/0000-0001-5615-2423 \\ Federal Rural University of the Amazon, Brazil \\ E-mail: alexcasseb@yahoo.com.br
}

\begin{abstract}
Free-living Columbidae are considered the second largest reservoir of Chlamydia psittaci, transmitting the agent to humans and other animals. The present study aimed to identify the presence of Chlamydia spp. in samples of lung and stool collected from free-living domestic pigeons (Columba livia domestica) captured at the Mangal das Garças Naturalistic Park in Belém, Pará, Brazil, using semi-nested polymerase chain reaction, and also correlate the clinical and post-mortem findings of animals positive for Chlamydia spp. Among the 45 animals analyzed, $10(22.2 \%)$ were positive for Chlamydia spp.; the positive findings originated from $5(50 \%)$ lung samples and $5(50 \%)$ stool samples, with no overlap between animals and samples. None of the animals evaluated in this study showed clinical signs of chlamydiosis; rather, these were only found during necropsy of positive animals, mainly through pulmonary, hepatic, splenic, and intestinal changes. These findings demonstrate that free-living pigeons can be reservoirs of Chlamydia spp. and transmit the agent silently to humans and animals, which is concerning for public and animal health, since these birds are easily found in urban areas cohabitating with humans, other species of birds, and other animals.
\end{abstract}

Keywords: Animal health; Chlamydiosis; Columbidae.

\title{
Resumo
}

Columbídeos de vida livre são o segundo maior reservatório de Chlamydia psittaci, transmitindo o agente para humanos e animais. Este estudo teve como objetivo identificar a presença de Chlamydia spp. em amostras de pulmão e fezes de pombos domésticos de vida livre (Columba livia domestica), capturados no Parque Naturalístico Mangal das Garças em Belém, Pará, Brazil, utilizando a reação em cadeia pela polimerase semi-nested e correlacionando os achados clínicos e post-mortem dos animais positivos para Chlamydia spp. Dentre os 45 animais avaliados, 10 (22.2\%) foram positivos para Chlamydia spp.; os achados positivos foram de $5(50 \%)$ amostras de pulmão e 5 (50\%) de amostras de fezes, sem sobreposição entre animais e amostra. Nenhum dos animais avaliados nesse estudo manifestaram sinais clínicos de clamidiose; em vez disso os achados dos animais positivos só foram encontrados durante a necropsia, principalmente com alterações pulmonares, hepáticas, esplênicas e intestinais. Esses achados demonstraram que os pombos de vida livre podem ser reservatórios de Chlamydia spp. e transmitir o agente silenciosamente para humanos e animais, o que seria preocupante para a saúde pública e animal, uma vez que essas aves são facilmente encontradas coabitando em áreas urbanas com humanos, outras espécies de aves e outros animais. Palavras-chave: Saúde animal; Clamidiose; Columbidae.

\section{Resumen}

Los columbidos de vida libre son el segundo reservorio más grande de Chlamydia psittaci, que transmite el agente a humanos y animales. Este estudio tuvo como objetivo identificar la presencia de Chlamydia spp. en muestras de pulmón y heces de palomas domésticas de vida libre (Columba livia domestica), capturados en el Parque Natural Mangal das Garças en Belém, Pará, Brasil, usando la reacción en cadena de la polimerasa semi-anidada y correlacionando los hallazgos clínicos y post-mortem de animales positivos para Chlamydia spp. Entre los 45 animales evaluados, $10(22,2 \%)$ fueron positivos para Chlamydia spp .; los hallazgos positivos fueron de 5 (50\%) muestras de pulmón y $5(50 \%)$ de muestras de heces, sin superposición entre los animales y la muestra. Ninguno de los animales evaluados en este estudio mostró signos clínicos de clamidiosis; en cambio, los hallazgos de animales positivos solo se encontraron durante la necropsia, principalmente con alteraciones pulmonares, hepáticas, esplénicas e intestinales. Estos hallazgos demostraron que las palomas de vida libre pueden ser reservorios de Chlamydia spp. y transmitir el agente silenciosamente a humanos y animales, lo que sería de preocupación para la salud pública y animal, ya que estas aves se encuentran fácilmente cohabitando en áreas urbanas con humanos, otras especies de aves y otros animales.

Palabras clave: Salud animal; Clamidiosis; Columbidae.

\section{Introduction}

The genus Chlamydia is comprised of obligate intracellular gram-negative bacteria, responsible for causing systemic disease in animals and humans (Raso, 2014). The Chlamydiaceae family is composed of the only genus Chlamydia and currently has eleven species: C. psittaci, C. muridarum, C. suis, C. trachomatis, C. abortus, C. caviae, C. felis, C. pecorum, C. pneumoniae, C. avium and C. gallinacean (Jeong et al., 2017). Of these, C. psittaci is the species most commonly related to 
infections in birds and humans (Wang et al., 2018). This species is divided into nine genotypes based on the outer membrane protein, designated A-F, E / B, M56, and WC, and has been isolated worldwide in approximately 470 distinct avian species, with greater occurrence in parrots and columbids (Raso, 2014; Jeong et al., 2017).

Free-living Columbidae are considered the second largest reservoir of $C$. psittaci, transmitting the agent to humans and other animals through the inhalation of contaminated aerosols released by stools, secretions, carcasses, feathers, and nest remnants contained in the environment, or indirectly through contact with unhygienic fomites, or ingestion of contaminated food and/or water (Haag-Wackernagel \& Vanrompay, 2009; Zhang et al., 2015).

Free-living domestic pigeons (Columba livia domestica) are common carriers of Chlamydia spp., releasing the bacteria intermittently in the environment regardless of the development of symptoms (Sachse et al., 2012). The presence of these birds in squares, streets, public buildings, open markets, zoo botanical parks, and in rural areas, cohabitating with humans and other domestic or free-living birds, represents a great risk to public and animal health (Burt et al., 2018).

Therefore, the present study aimed to identify the presence of Chlamydia spp. in lung and stool samples collected from free-living domestic pigeons, captured at Mangal das Garças Naturalistic Park in Belém, Pará, Brazil, through seminested polymerase chain reaction (PCR), as well as to correlate the clinical and post-mortem findings of positive animals.

\section{Material and Methods}

\subsection{Bioethics and biossecurity committee approval}

All the work described was authorized by the Animal Use Ethics Committee of the Federal University of the Amazon and by the Brazilian Institute of Environment and Renewable Natural Resources, under the records no. 23084.007559/2016-59 and 69765274, respectively.

\subsection{Animal capture and study location}

Forty-five free-living pigeons were captured in the Mangal das Garças Naturalistic Park, which is a space destined to tourism, leisure, and environmental education, located in the city of Belém, state of Pará (PA). Pigeons were captured from January to October 2015; for this purpose, a circular net with edges made of polyvinyl chloride pipes was suspended over a feeder that served as an attraction for animals.

\subsection{Clinical evaluation}

The animals were captured and subjected to a clinical evaluation to identify signs of general disease. The following parameters were evaluated: sex (male or female), ages (young or adult), flesh state classification according to Fontenelle \& Barros, (2014), general state (active animals classified as “good”, listless animals classified as "bad”), plumage (classified as "good" or "bad", according to the appearance), presence or absence of ectoparasites, condition of visible mucous membranes, and presence/absence of external lesions.

\subsection{Sample collection}

For the collection of lung and stool samples, animals were anesthetized using a combination of ketamine and xylazine as described by Altman et al., (1997) and euthanized by cardiac exhaustion. Subsequently, the birds were submitted to necropsy to view the condition of the organs and collect the samples. Lung fragments and stool samples were collected, packaged in individual cryogenic tubes, and stored in a freezer at $-80^{\circ} \mathrm{C}$ until laboratory tests were carried out. 


\subsection{DNA extraction and molecular analysis of Chlamydia spp.}

For the extraction of the bacterial genetic material from the lung samples, $10 \mathrm{mg}$ of lung tissue from each bird were used, plus $1 \mathrm{~mL}$ of lysis buffer solution from the extraction kit iPrep ${ }^{\mathrm{TM}}$ ChargeSwith gDNA Tissue Kit (Invitrogen ${ }^{\mathrm{TM}}$, Carlsbad, $\mathrm{CA}$ ) and the process by Tissue Lyser II (Qiagen Ltd., Germantown, MD) at $25 \mathrm{~Hz}$ for $5 \mathrm{~min}$ using a $5 \mathrm{~mm}$ steel sphere. The supernatant from each sample was transferred to a new individual microtube, $10 \mu \mathrm{L}$ of RNAse were added, followed by incubation for $10 \mathrm{~min}$ at $25^{\circ} \mathrm{C}$ and addition of $20 \mu \mathrm{L}$ of proteinase $\mathrm{K}$. Subsequently, the tubes were incubated at $55^{\circ} \mathrm{C}$ for 1 hour. Bacterial DNA purification was performed using the kit Prep $^{\mathrm{TM}}$ gDNA Tissue (Invitrogen ${ }^{\mathrm{TM}}$, Carlsbad, CA) and iPrep ${ }^{\mathrm{TM}}$ Purification Instrument. The extraction of bacterial genetic material from stool samples was performed using Purelink ${ }^{\mathrm{TM}}$ Purification Kit (Invitrogen ${ }^{\mathrm{TM}}$, Carlsbad, CA). All extraction kits were used according to the manufacturer's instructions.

Semi-nested PCR for Chlamydia spp. were performed using three primers: A (5'CAGGATATCTTGTCTGGCTTTAA-3'), B (5'-GCAAGGATCGCAAGGATC3') and

(5'TTAGAGGTGAGTATGAAAAAACTC-3') which target the conserved region of the Chlamydia major outer membrane protein gene (Buxton et al., 1996). In the first reaction, the PCR cycling conditions were: $10 \mathrm{~min}$ at $94^{\circ} \mathrm{C}, 34$ cycles at $94^{\circ} \mathrm{C}$ for $1 \mathrm{~min}$, hybridization at $52^{\circ} \mathrm{C}$ for $1 \mathrm{~min}$, extension at $72^{\circ} \mathrm{C}$ for $1 \mathrm{~min}$ and final extension at $72^{\circ} \mathrm{C}$ for $4 \mathrm{~min}$; primers $\mathrm{A}$ and $\mathrm{B}$ were used, producing 260 base-pair (bp) amplicons. The same cycling conditions was used for the second reaction, but with Primers B and C and with amplified fragments of approximately $165 \mathrm{bp}$. Amplified DNA samples were electrophoresed with $2 \%$ agarose gel and stain with SYBR ${ }^{\circledR}$ Safe $\left(\right.$ Invitrogen $^{\mathrm{TM}}$, Carlsbad, CA) and the amplified products were visualized with a UV transilluminator (Raso et al., 2006).

\section{Results}

Among the 45 domestic pigeons used in this study, 18 (40\%) were males and 27 (60\%) were females. As for the flesh state, 7 (15.6\%) animals received a "good" score, 14 (31.1\%) received a "regular" score and 24 (53.3\%) received a "bad" score. In the general status parameter, all pigeons were active and responsive to external stimuli and were classified as "good". Regarding the plumage, 31 (68.8\%) birds were classified as "good" and 14 (31.2\%) were classified as "bad".

About the state of the visible mucous membranes, $36(80 \%)$ birds had normal oral mucosa and $9(20 \%)$ showed changes in coloring; 27 (60\%) had normal ocular mucous membranes and $18(40 \%)$ had changes; 38 (84.5\%) had a normal nasal mucosa and $7(15.5 \%)$ showed changes; $39(86.6 \%)$ had a normal cloacal mucosa while $6(13.4 \%)$ showed defects. All the pigeons evaluated carried ectoparasites; 4 (8.8\%) were parasitized by chewing lice, 5 (11.2\%) had only hematophagous flies of the genus Pseudolynchia spp., and 36 (80\%) showed a parasitic association between chewing lice and hematophagous flies.

A total of $10(22.2 \%)$ pigeons were positive for Chlamydia spp., with $5(50 \%)$ positive results originating from lung samples and $5(50 \%)$ from stool samples, with no overlap between animals and samples. Positive lung samples originated from $4(80 \%)$ adult male pigeons and $1(20 \%)$ young female, while positive stool samples originated from $3(60 \%)$ males and 2 (40\%) females. Among these, $2(40 \%)$ were adults and $3(60 \%)$ were young.

\section{Discussion}

None of the animals evaluated in this study showed clinical signs of Chlamydia spp. during the external inspection. Bougiouklis et al. (2000) found that young birds of approximately 16 weeks of age with Chlamydia spp. manifested severe clinical signs, while adult pigeons are asymptomatic and can become chronic carriers of the bacteria. According to Vanrompay 
et al. (1995), pigeons only show symptoms of Chlamydia spp. when they have concomitant infections, presenting mainly with respiratory symptoms and loss of flight performance.

The presence of virulent strains of Chlamydia spp. associated with stress conditions such as overpopulation, reproductive period, nutritional deficiency, migration, and abrupt environmental changes favor the clinical manifestation of chlamydiosis in domestic pigeons; the intermittent elimination of the infectious agent in the feces may also occur (Salinas et al., 1993; Harkinezhad et al., 2009). In the present study, Chlamydia spp. was detected in a stool sample from a female in the reproductive period.

Regarding age, $60 \%$ of the positive pigeons in this study were adults and $40 \%$ were young. Geigenfeind et al. (2012), in their research on the prevalence of $C$. psitacci in the free-living pigeon population in Switzerland, detected the presence of the bacteria in the feces of young and adult birds, demonstrating that these animals can excrete the etiological agent into the environment throughout life.

Previous articles have described that the main route of transmission of Chlamydia spp. between birds is horizontal, through the inhalation of aerosols released by dried secretions and feces, feather powder, and contaminated carcasses (Kaleta $\&$ Taday, 2003). However, vertical transmission from the female to the egg may also occur. Adult birds are much more likely to come into contact with Chlamydia spp. present in the environment than young birds, since they have ample flight capacity and are often in direct contact with other birds, mammals, and humans (Wang et al., 2018).

All positive pigeons showed macroscopic pathological changes in organs such as liver, lung, intestine, and spleen during necropsy. According to Vanrompay et al. (1995), the severity of the injuries caused by Chlamydia spp. in the infected bird organs depends on factors such as the virulence of the bacterial strain, host susceptibility, exposure route, and presence/absence of other diseases. Lesions such as aerosaculitis, pericarditis, pneumonia, hepatitis, splenitis, enlargement with loss of consistency of organs such as the liver and spleen, edema and lung congestion, and enteritis with congestion of the intestinal mucosa, are common macroscopic findings in pigeons infected with Chlamydia spp. (Vanrompay et al., 1995; Bougiouklis et al., 2000; Raso, 2014; Knittler \& Sachse, 2015).

This study showed a $22.2 \%$ prevalence of Chlamydia spp. in free-living domestic pigeons captured in a natural park in Belém-PA, Brazil. Animal age and sex were not determining factors for the molecular detection of the agent in lung and stool samples; no positive birds showed characteristics signs of chlamydiosis during clinical evaluation, which were restricted to necropsy findings.

\section{Conclusion}

The results of the study indicate that free-living pigeons in Belém can be reservoirs of Chlamydia spp. and be able to silently transmit the agent to humans and animals, which is worrying in terms of public and animal health, since these birds are easily found in urban and rural areas cohabitating with humans, other species of birds, and other animals.

In this case, it is of major interest to the scientific community that research on Chlamydia spp. keep going deeper, with the help of other methodologies and also with animals of other species, which have interaction with free-living pigeons, especially in urban centers.

The information obtained can contribute to elucidate the casuistic of infection, considering that in the study there was a prevalence of $22.2 \%$ among the animals analyzed and no positive pigeon showed characteristic signs of chlamydiosis during the clinical evaluation. Thus, all the information generated can contribute to the adoption of prophylactic and control measures. 
Research, Society and Development, v. 10, n. 9, e1710917747, 2021

(CC BY 4.0) | ISSN 2525-3409 | DOI: http://dx.doi.org/10.33448/rsd-v10i9.17747

\section{References}

Altman, R. B., Clubb, S. L., Dorrestein, G. M., \& Quesenberry, K. (1997). Avian Medicine and Surgery. Philadelphia: W. B. Saunders Company.

Burt, S. A., Röring, R. E., \& Heijne, M. (2018). Chlamydia psittaci and C. avium in feral pigeon (Columba livia domestica) droppings in two cities in the Netherlands. Veterinary Quarterly, 38(1), 63-66.

Buxton, D., Rae, A. G., Maley, S. W., Thomson, K. M., Livingstone, M., Jones, G. E., \& Herring, A. J. (1996). Pathogenesis of Chlamydia psittaci infection in sheep: detection of the organism in a serial study of the lymph node. Journal of comparative pathology, 114(3), 221-230.

Bougiouklis, P., Papaioannou, N., Georgopoulou, I., Iordanidis, P., Vlemmas, I., Lekkas, S., \& Siarkou, V. (2000). Chlamydia-induced bilateral ectropion of the inferior eyelids in pigeons. Avian diseases, 372-378.

Fontenelle, J. H., \& Barros, L. A. (2014). Ciconiiformes, Pelacaniformes, Griuformes e Carianiformes (Maguari, Tuiuiu, Garça, Socó, Guará, Colhereiro, Jacamina, Saracura, Frango d’água, Grou e Siriema). In: CUBAS, Z.S. et al. Tratado de animais selvagens. São Paulo: Roca, 2014. Cap. 24. p. 441-445.

Geigenfeind, I., Vanrompay, D., \& Haag-Wackernagel, D. (2012). Prevalence of Chlamydia psittaci in the feral pigeon population of Basel, Switzerland. Journal of medical microbiology, 61(2), 261-265.

Haag-Wackernagel, D., \& Moch, H. (2004). Health hazards posed by feral pigeons. Journal of Infection, 48(4), 307-313.

Harkinezhad, T., Geens, T., \& Vanrompay, D. (2009). Chlamydophila psittaci infections in birds: a review with emphasis on zoonotic consequences. Veterinary microbiology, 135(1-2), 68-77.

Jeong, J., An, I., Oem, J. K., Wang, S. J., Kim, Y., Shin, J. H., \& Jheong, W. (2017). Molecular prevalence and genotyping of Chlamydia spp. in wild birds from South Korea. Journal of Veterinary Medical Science, 16-0516.

Knittler, M. R., \& Sachse, K. (2015). Chlamydia psittaci: update on an underestimated zoonotic agent. Pathogens and disease, 73(1), 1-15.

Raso, T. F. (2014). Clamidiose- novas abordagens diagnósticas e terapêuticas. In: Cubas, Z. S., Silva, J. C. R., Catão-Dias, J. L. Tratado de animais selvagens. São Paulo: Roca, 2014. Cap. 67. p. 1369-1381.

Raso, T.F., Seixas, G. H. F., Guedes, N. M. R., \& Pinto, A. A. (2006). Chlamydophila psittaci in free-living Blue-fronted Amazon parrots (Amazona aestiva) and Hyacinth macaws (Anodorhynchus hyacinthinus) in the Pantanal of Mato Grosso do Sul, Brazil. Veterinary Microbiology, 117(2-4), 235-241.

Sachse, K., Kuehlewind, S., Ruettger, A., Schubert, E., \& Rohde, G. (2012). More than classical Chlamydia psittaci in urban pigeons. Veterinary microbiology, 157(3-4), 476-480.

Salinas, J., Caro, M. R., \& Cuello, F. (1993). Antibody prevalence and isolation of Chlamydia psittaci from pigeons (Columba livia). Avian diseases, 523-527. Vanrompay, D., Ducatelle, R., \& Haesebrouck, F. (1995). Chlamydia psittaci infections: a review with emphasis on avian chlamydiosis. Veterinary microbiology, 45(2-3), 93-119.

Wang, X., Zhang, N. Z., Ma, C. F., Zhang, X. X., Zhao, Q., \& Ni, H. B. (2018). Epidemiological investigation and genotype of Chlamydia exposure in pigeons in three provinces in northern China. Vector-borne and Zoonotic Diseases, 18(3), 181-184.

Zhang, Q., Wu, Z., Sun, R., Chu, J., Han, E., Zhang, Y., \& Ni, P. (2015). Whole-genome sequences of Chlamydia psittaci strain HJ, isolated from meat pigeons with severe respiratory distress and high mortality. Genome announcements, 3(2), e00035-15. 